\title{
CONTENT GRADATION OF SUNDANESE TEXTBOOKS FOR JUNIOR HigH SCHOOL AND SENIOR HIGH SCHOOL (Review of Facts, Concepts, Principles, AND Procedures in The Field of SUNDANESE LANGUAGE STUdY IN 2013 LoCAl CONTENT CURRICULUM REVISED 2017)
}

\author{
Dingding Haerudin ${ }^{1)}$, Dedi Koswara ${ }^{2)}$, Amanda Puspanditaning Sejati ${ }^{3)}$ \\ ${ }^{1)}$ Universitas Pendidikan Indonesia, Bandung, Indonesia \\ E-mail: dingding.haerudin@upi.edu \\ ${ }^{2)}$ Universitas Pendidikan Indonesia, Bandung, Indonesia \\ E-mail:dedi.koswara@upi.edu \\ ${ }^{3)}$ Universitas Pendidikan Indonesia, Bandung, Indonesia \\ E-mail: amanda.puspanditaning@upi.edu
}

\begin{abstract}
The main reason for conducting this research is that Sundanese textbooks do not describe the material gradation standards according to the needs and background of students at each level of Education, in addition to not presenting a systematic material structure. In connection with the reason above, the purpose of this study is to examine the gradations and structure of the material contained in the Sundanese textbook for Junior High School/MTs and Senior High School/Vocational/MA students. The method used in this research is the description method. While the data collection technique used in this research is library research techniques. The technique is used to describe data based on gradations and structure of subject presented in Sundanese textbooks based on education levels. The data processed in this study is Sundanese language learning materials including 1) literary forms of poetry: poetry, circumcision, wawacan, satire, pupujian, sawer, and kawih; 2) literary forms of prose: fairy tales, short story, novels, puppet story, and drama; 3) non-literary texts: speeches, writers, letters, reports, debates, interviews, and reports reading. As for, the source of the data is Sundanese textbooks for Junior High School/MTs and Senior High School/Vocational/MA students based on the 2013 Local Content Curriculum Revised 2017. The finding of this study is that the composition of Sundanese textbook material for Junior High School/MTs and Senior High School/Vocational/MA students in accordance with the 2013 Local Content Curriculum Revised 2017, nevertheless, not paying attention to the gradation of the material. Things that unintentionally missing from the authors are 1) gradation of writing indicators from competencies achievement or learning objectives, 2) scope of material presentation and depth of material, and 3) variations of operational verbs on the writing tasks. This research can be used as a consideration in compiling the material presented in the textbook, so that the content presented ca be in accordance with students' needs and background based on their level of education.
\end{abstract}

Keywords: curriculum; concepts; factual; gradation principles; procedures; textbooks

\section{INTRODUCTION}

The quality of learning outcomes at every level of education cannot be disconnected from the role of textbooks, as in the case of Sundanese language lessons. Therefore, the material presented in the textbook must be adjusted to the characteristics and background of students who use it. But in reality, Sundanese textbooks that are used generally do not describe appropriate gradations to the level of education, both related to content standards and graduate competency standards (Haerudin, 2020).

A good book is a book that presents strategies and thinking skills and the relationship between one thing and another. Alwasilah (2005, in Fauziah, 2015) states that there are a number of criteria that the authors of a textbook need to concern to i.e. 1) the author's expertise should be in accordance with the subject matter he is writing; 2) look at 
curriculum guidelines to ensure that the material contained in the curriculum is included in textbooks; 3) experts textbook writing; 4)professional organization existence; 5) accompanied by a professional editor. Alwasilah further states that solid textbooks appear as the result of a series of professional steps i.e. the manuscript writer, review and revision of the manuscript. Field trial results, trial results evaluation, manuscripts revise based on evaluation results, and mass-produced. The evaluation includes the documentation of teacher and student impressions when they use the textbooks.

The 2013 curriculum which uses a scientific approach to emphasize integrated thematic learning is one learning approach where competencies (attitudes, knowledge, skills) from various subjects are combined into one to form a deeper and meaningful understanding for students. This is relevant to Permendikbud No. 67 of 2013 "concerning the basic framework and structure of the primary school curriculum, i.e. the 2013 curriculum was developed through perfecting the mindset of passive learning into active learning.

Januszewki and Molenda (2008, in Suistika \& Ishartiwi, 2019) states that "attractive learning should have one or more of the following qualities i.e. a) Provides challenges and raises high expectation; b) Relevant and authentic with students' past experiences and their future needs; c) Have a humorous aspect or enjoyable element; d) Attract attention through new things; e) Intellectual and emotional involvement; f) Connected with students' interests and objectives; and g) Using various forms of representation (for example, audio and visual)".

Based on the above opinions, Sundanese textbooks must also bear in mind to these provisions. Many Sundanese textbooks used as a guide for teachers in schools do not take care of the systematic structure and gradation of material difficulty level. The scope and sequence of materials in the form of concepts learned by SMP/MTs students must actually be differentiated from those given for SMA/K/MA. In general, the differences related with the presentation of facts, the sequence of theories such as concepts and principles, as well as the procedures such as the differentiation of systematic presentation are not yet clear at each level of education.

There are various studies on examining textbooks that had conducted. Among which is the research conducted by Suratni and Paat (2014). The focus of this research is more on examining the feasibility aspects of presenting content, language, and graphics in general. Other research was conducted by Nurdeani (2016) that describes the feasibility of writing English subject matter standards for 3rd Grade of Elementary Schools. Mahmudah (2016) also conducted a study of a textbook that focused on the quality of book contents in general.

There are only few limited studies comparing the gradation and structure of Sundanese language textbooks. Therefore, this study presents the results of the gradations analysis contained in Sundanese language textbook of the 2013 Local Content Curriculum which was revised in 2017.

Based on the above background, the researcher formulates the research problems as follows: How is the gradation of Sundanese textbook material for junior and senior high school levels composed based on revised 2013 local content curriculum? In addition, the purpose of this research is to describe gradation of Sundanese textbook material for junior and senior high school levels composed based on revised 2013 local content curriculum.

\section{METHODOLOGY}

This section discusses research methods and techniques, data and research data sources, as well as research instruments and its steps. To solve various problems and achieve the objectives in this study, descriptive qualitative methods were used. This method is used to describe the findings obtained from the results of the analysis.

Data collection techniques used are literature review techniques. Information obtained from written sources is reviewed to answer problems and realize research objectives based on the instruments established by Sugiyono (2008:83). The data obtained is inventoryed based on the problems that will be studied relating to: 1) of material gradation; and 2) the presentation structure of the material contained in the Sundanese language textbooks for SMP/MTs and SMA/SMK/MA.

The data collected is then processed based on the problem and the purpose of the research carried out by examining all data contained in Sundanese textbooks based on education levels. The data found is then inventoried based on the problems that will be studied regarding: 1) material gradation based on education level; 2) the structure of the material which includes the aspects of language skills, facts, concepts and principles of linguistic and literature, as well as the procedures for their presentation.

The steps are as follows: (1) selecting and verifying every data found; (2) classifying; (3) analyzing; (5) describing; and (6) composing research reports. Based on the description above, the flow of this research can be illustrated in the following chart.

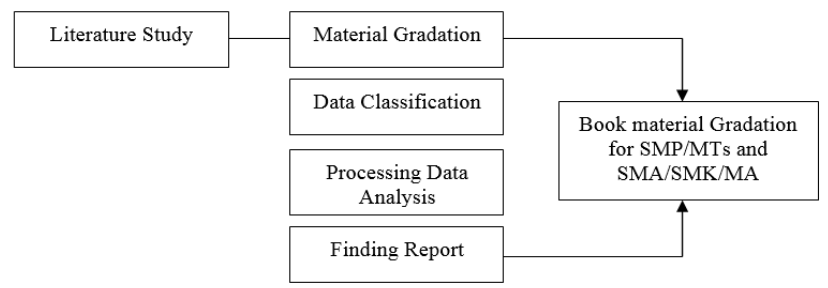

Fig. 1 Research flow.

The data processed in this study are teaching material presented in textbooks of junior and senior high schools guided by the 2013 Local Content Curriculum 2017 Revised. Such Data includes a) teaching materials in the form of the fact of sisindiran, dongeng (fairy tales), sajak (rhymes), carpon (short stories), novels, kawih, articles, news and biantara (speech).

The data sources of this research are 1) Rancagé textbook Diajar Bahasa Sunda pikeun Murid SMP/MTs Kelas VII, VIII, IX; and 2) Rancagé textbook Diajar Bahasa Sunda pikeun Murid SMA/MA/MAK Kelas X, XI, XII published by Pustaka Jaya, 2018 which is based on Core Competencies and Basic Competencies (KIKD) Curriculum 2013 Revised 2017. 


\section{RESULT AND DISCUSSION}

In connection with the formulation and objectives of the research stated above, the results of this study describe the gradations of material written in Sundanese textbooks for Junior and Senior High School. The data analyzed were sourced from the textbooks entitled Rancage Diajar Bahasa Sunda (RDBS) for students of SMP/MTs Grade VII, VIII, IX; and Rancagé Diajar Bahasa Sunda (RDBS) Text Books for students of SMA/MA/MAK grade X, XI, XII published by Pustaka Jaya, 2018.

The material studied includes sisindiran, dongeng (fairy tales), sajak (rhymes), carpon (short stories), novels, kawih, articles, news and biantara. More detailed data analysis results are described as follows.

\section{A. Sisindiran Material}

The formulation of KD 3 for sisindiran material in curriculum 2013 revised edition of Junior High class VIII: Understanding and identifying social functions, structures and linguistic elements contained in sisindiran, KD 4: Expressing sisindiran in written and oral form (for example through posters, memes, or tempas sindir) With regard to structure, expression, and lentong kalimat. While the formulation of KD 3 for SMA class XI: Analyzing the content, structure, and sisindiran linguistic aspects. KD 4: To compile and display sisindiran in accordance with the context and social function.

Pay attention to the operational verb (KKO) at KD3 of sisindiran material for junior high school class VIII is in the category of LOTs-HOTs namely understanding (C2) and identifying (C4), while KD4 in the HOTs category is expressing (C6). KKO for the Sisindiran material at SMA class XI both KD3 and KD4 is in the category HOTs i.e. analyze (C4), compose (C6) and display (C6). Based on the results of the analysis of $\mathrm{KKO}$ on KD 3 and 4 It is stated that the scope of sisindiran material in junior secondary school is lower than senior high school. This means that sisindiran learning material in Senior high school is an advanced learning material of sisindiran in junior high school.

The materials presented in junior high school RDBS in the form of facts include Paparikan text, Rarakitan text and Wawangsalan text. At senior high school level is also the same i.e. includes the texts of paparikan, rarakitan, and wawangsalan. The material in the form of Concepts/principles in RDBS for Junior and senior high school includes the limitation, the character and rules of sisindiran text. The procedure for presentation in RDBS at junior high school level includes Maca sisindiran (reading), Mahamkeun sisindiran (Comprehension) and Exercise 1, form and structure of sisindiran and exercise 2, composing sisindiran and exercise 2-exercise 3, performing sisindiran dan exercise 4, Sesembén: Sundanese language pakeman (rules). While for senior high school level includes Mikawanoh sisindiran and Exercise 1, Nyangkem sisindiran and Exercise 2, Nganalisis sisindiran and Exercise 3, Ngarang sisindiran and Exercise 2, Sesembén: special words. The materials presented in junior high school RDBS in the form of facts include Paparikan text, Rarakitan text and Wawangsalan text: special words.

\section{B. Fairytale Material}

KD 3 formulation for fairy tale material in the curriculum 2013 revised edition for the seventh-grade junior high school: Identifying the values in the sasakala fairy tale in accordance with social functions, text structure and linguistic elements. KD 4-1: Compiling a mind map/fairy tale concept in accordance with social functions, text structure and linguistic elements. KD 4-2: Communicating fairy tales in one's own language according to social functions, text structure and linguistic elements. Whereas KD 3 formulation for Grade X of senior High School: Comparing various types of the fairy tale based on content, structure, and linguistic aspects. KD 4 : Performing various types of fables through storytelling, monologue, or dramatization.

Noting KKO KD3 for fairy tale material for class VII SMP is in the category of LOTs namely understanding (C2) and Drafting (C3), while the KD4 in the HOTs category is to communicate (C6). KKO for fairy tale material in SMA class $\mathrm{X}$ both $\mathrm{KD} 3$ and $\mathrm{KD} 4$ are in HOTs category namely comparing (C4) and displaying (C6). Based on the results of the analysis of KKO on KD 3 and 4 stated that the scope of the fairytale material in Junior high school is lower than Senior high school. It means that the content of storytelling teaching in high school is an advanced fairytale learning material in junior high school.

The materials presented in junior high school RDBS in the form of facts include: Fairy tales titled "Talaga Bagendit", "Sasakala Uncal Tandukan", "Sasakala Curug Santri", "Sasakala Lembur Bunihayu", and "Sasakala Kuya Ngagandong Imahna". The high school includes: The fairy tale text titled "Talaga Warna", "Budak Hideung", and "Munding Jeung Oray Totog". Material in the form of concept presented in junior high school include: educational Values and Fable fairy tales, Legends, Sage, parable, mite, and Pamuk (p. 60-61). As for the senior high school include: Fairy tales definition, fairy tale Principles: no author/anonym, unreasonable/pamohalan, hereditary story; Fairy tale groups: Farabel, Fable, legends, mite; and fairy tale elements: themes, actors, character, plot, background, mandate, unreasonable (31-34). The procedure of presentation of material in junior high schools include: fairy tale reading-answering the practice of 1 , discussing the value of education in storytelling, understanding fairy tale-Exercises 2. Adding Insight into fairy tale-Exercise 3. While for the senior high school includes: Reading fairy-tale Exercise 1, Discussing the fairy tale, Writing a fairy tale, Storytelling (ngadongeng), Sesemben: about the season.

\section{Poetry Material}

KD 3 formula for poetry material in the 2013 curriculum revised edition for junior high school grade VII: Identifying the form and structure of texts, elements, linguistic aspects, and the content and mandate of poetry. KD 4: Reading/reciting poetry with appreciation and proper expression, based on to the structure of the text and linguistic elements. Whereas KD 3 formulation for grade X of senior high school: Analyzing the content, structure, and language 
aspects of poetry. KD 4: Performing poetry by reading, reciting, musicalising or dramatizing.

Noting KDO KKO for poetry material for Class VII Junior High School is in the category of LOT-HOTs namely reading (C1) and identifying (C4), while the KD4 in the HOTs category is reciting (C6). KKO for poetry material in High School Class X both KD3 and KD4 are in the category of HOTs namely analyzing (C4), displaying (C6) and reciting. Based on the results of the analysis of the KKO in KD 3 and 4 stated that the scope of the poem material in junior high school is lower than in senior high school. This means that the poetry learning material in senior high school is a continuation of the poetry learning material in junior high.

The material presented in the junior high school RDBS in the form of facts includes: a poem text entitled "Lemah Cai" by: Dedi Windyagiri, "Nu Metik Entéh" by: Agus Suherman, "Leumpang Peuting" by: Rachmat M. Sas. Karana, "Handapeun Langit Kota" by: Hadi AKS, "Tanah Sunda" by: Ajip Rosidi, "Gerilya" by: Rachmat M. Sas. Karana, "Sawah" by: Sayudi (pp. 87-104); whereas in senior high school the text of the poem covers "Pamanggih" by: Ayatrohaedi; "Meri" by: Apip Mustopa; "Kahirupan Ma Anah" by: Eddo S.Y.; "Balada Si Jago Ibro" by: Eson Sumardi; "Sarébu Bulan" by: Yus Rusyana; and "Statsion Tugu" by: Deden Abdul Aziz (pp. 133-146). The material in the form of concepts presented at junior high school includes: the definition of poetry; poetry reading techniques; poetic elements (sense, feeling, tone, intention ; discussion of "Nu Metik Entéh" poetry; write the titles of poetry collection books; and discuss connotative and denotative meanings; while at senior high school includes: definition of poetry; history of poetry development; author names and titles of poetry collection books; forms of poetry: epic poetry and lyric poetry; and elements of poetry: images, symbols, musicality, atmosphere and themes, theme, and language poetry. The procedure for presenting material at junior high school level covers: reading poetry (pp. 88-91); Explaining poetry (90-91); Rationalizing poetry case (91-94) followed by Exercise 1 (pp. 95-97), Exercise 2 (pg. 97-99), and Exercise 3 (pg. 99), writing poetry (pg. 99-100) followed by Exercise 4 (pg. 100-101), Sesembén (pg. 102-103), and vocabulary $\mathrm{p}$ (pg. 103- 104), while the senior high school level covers: Poetry reading ( $\mathrm{pp}$ 135-136) followed by Exercise 1 (pg 137); Explaining poetry case (pg 137); poetry structure comprehension (pg 138-143) followed by exercise 2 (p. 143); analyzing the Element of poetry (pp. 143-144) followed by Exercise 3 (pp. 144); Sesemben (p. 144); and vocabulary (pp. 145-146).

\section{Short Story Material}

KD 3 formula for short story material in the 2013 curriculum revised edition for junior high school class VIII: Understanding and identifying social functions, structures and linguistic elements of short story. KD 4: Responding to the values that exist in the short story by regarding to intrinsic elements, social functions, and linguistic aspects. Whereas KD 3 formula for grade XI Senior high school: Analyzing the contents, structure and language aspects of short story. KD 4:
Writing a simple short story by concerning about the structure and language rules.

Noting KKO KD3 and KD4 for short story material in SMP Class VIII is in the category of HOTs, namely identifying (C4) and responding (C5). KKO for short story material in Class XI senior high school both KD3 and KD4 are in the category of HOTs i.e. analyzing (C4), writing (C6). Based on the results of an analysis of KKO in KD 3 and 4 stated that the scope of short story material in junior high is lower than senior high school. It means that carpon learning material in senior high school is a continuation of short story learning material in junior high. The material presented in the junior high school RDBS in the form of facts includes: a short story text entitled "Duh Indung" by Tetti Hodijah, short story "Runtah" by Rahmaida, and carpon "Tarawéh" by Alzahra Pramanik. Whereas for senior high school includes: short stories texts titled "Kanyaah Kolot" by Karna Yudibrata, "Nu Katunda di Manonjaya" by Ahmad Bakri, and "Husu" by Risnawati. Material in concept form for SMP includes: short story structure namely theme, mandate, character, plot, background, point of view, language style, and and the title. Meanwhile, for senior high school include: the definition of short story, the characteristics of short story, short story as part of the literary work, the history of short story development, as well as the short story book collection of that received the Rancagé Prize. The procedure for presenting material at junior high school covers: (1) short story reading, (2) telling short story content (3) short story structure followed by Exercise 1, (4) short story writing followed by Exercise 2, (5) sesemben kecap rajekan (6) vocabulary. While for senior high school it includes: (1) short story reading followed by Exercise 1, (2) medar short story followed by Exercise 2, (3) analyzing short story followed by Exercise 3, (4) short story writing followed by Exercise 4, (5) sesembén about conjunction, and (6) vocabulary.

Noting the composition of the short story material presented in RDBS in general it has fulfilled the material aspects in the form of facts, concepts, and procedures. However, if you pay attention to the scope of the material, it has not shown the level of gradation based on the level of education. Likewise, if you pay attention to the learning objectives and evaluation, it does not fully describe the expected KD 3 and 4. It means that the scope of short story material presented in RDBS at senior high school is not higher than for junior high school.

\section{E. Novel Material}

KD 3 formula for novel material in the 2013 Curriculum revised edition for Junior high school Class IX: Identifying the intrinsic elements of the novel regarding to social functions, text structures, and proper language elements and its context. KD 4: Describing the content of the novel by observing the social functions, text structures, and elements of the correct and context-based linguistic. While the formulation of KD 3 for SMA class XI: Analyzing the content, structure, and linguistic aspect of the novel. KD 4: Presenting the results of the novel analysis through various media (such as scenes, 
illustrated story, animation) with attention to the structure and rules of the linguistic.

Noting KKO KD3 and KD4 novel material in SMP Class IX is in the LOTs and HOTs categories, namely identifying (C1) and describing (C6). Likewise, KKO for novel material in class XI Senior high School both KD3 and KD4 is also in the category of HOTs i.e. analyzing (C4), presenting (C6). Based on the results of the analysis of KKO on KD 3 and 4 It is stated that the material scope of the novel in SMP is lower than senior high school. This means that novel learning material in senior high school is a continuation of the novel learning material in junior high school.

The material presented in RDBS for junior high school includes facts: excerpts from the novel entitled "Misteri Haur Geulis" by Dadan Sutirna, excerpts from "Babalik Pikir" novel by Samsoedi, and excerpts from "Si Bedog Panjang" novel by Ki Umbara; while for senior the high school includes: the text of the exception of the novel "Manéhna" by Syarif Amin, excerpts from "Kembang-kembang Anten" novel by Aam Amalia, and excerpts from "Béntang Pasantrén" novel by Usép Romli. The material in the form of concepts for junior high schools includes: The Origins and History of novels, definitions of novels, titles and authors of novels, novel elements, and discussion of "HaurGeulis" content novel by DadanSutisna. As for the high school levels include: The origins of the novel term, the title of the first published novel, some titles of novels and authors. The procedure for presenting novel material at junior high school includes: (1) reading novels, (2) novels explanation, (3) novels comprehension followed by Exercise 1, (4) novels content review, (5) sesembén(additional activity)on kitchen utensils , and (6) vocabulary; while for senior high school it includes: (1) reading novel followed by Exercise 1, (2) medar (Explaining) novels followed by Exercise 2, (3) comprehension on intrinsic novel elements followed by Exercise 3, (4) analyzing the novel followed by Exercise 2, (5) sesembén about direct sentence, and (6) vocabulary.

\section{F. Kawih Material}

KD 3 formula for kawih material in the 2013 curriculum revised edition for junior high school class VIII: Identifying social functions, the structure of kawih texts, and linguistic elements. KD 4: Communicating or singing kawih with regard to vocal expressions and techniques. Whereas KD 3 formula for Class X: Comparing the form, structure and linguistic elements of classical and pop Sundanese song texts. KD 4: Creating classical and pop Sundanese song and singing them by giving attention to form, expression, and intonation (lentong).

Noting KKO KD3 and KD4 kawih material in junior high school class VIII are in the LOTs and HOTs categories, namely identifying (C1) and communicating (C6). KKO for kawih material in senior high school class $\mathrm{X}$ both KD3 and KD4 are in the category of HOTs namely analyzing (C4), presenting (C6). Based on the results of the analysis of KKO in KD 3 and 4 it is stated that the scope of kawih material in junior high schools is lower than senior high schools. It means that kawih learning material in senior high school is a continuation of kawih learning in junior high school.

The material presented in RDBS for junior high school in the form of facts includes the text song titled "Cinta Nusa" by Mang Koko, "Jang" by Oo B, and "Tanah Sunda"; while for senior high school it includes the text song entitled "Écéng Gondok", "Énjing Deui" by Ubun Kubarsah, "Kamana Akang" by Gun Gunawi, and "Béntang Kuring" by Yus Wiradireja. The material in the form of concepts for junior high school includes the explanation of kawih term, the terminology for people involved in kawih activities, kawih intrinsic elements such as images, symbols, musicalization, mental elements consisting of themes, tastes, tones, and mandates, as well as array examples, verse, number of syllables, and the musicalisation at each end of the array (pp. 13-18); while at senior high school it includes: the origins of kawih term, the term kawih in old Sundanese script "Sanghyang Siksa Kandang Karesian", the differences between classical and pop kawih, and discussion of "Écéng Gondok" song (pp. 63-69). The procedure for presenting the material junior high school includes: (1) Singing Kawih (song) followed by Exercise 1, (2) Comprehending the content of Kawih by Exercise 2, (3) Text Structure of Kawih lyrick (4) Observing Kawih followed by Exercises 3 and 4, (5) Additional activity about the language style, and (6) Vocabulary (pp. 10-22); For senior high school it includes: (1) listening to kawih followed by Exercise 1, (2) Observing the content of Kawih followed Exercise 2 and 3, (3) Explaining kawih followed by Exercise 4, (4) Singing kawih (5) Additional activity about metaphorical language style, and (3) Explaining kawih followed by Exercise 4, (4) Singing kawih (5) Additional activities about metaphorical language styles, and (6) Vocabulary.

\section{G. Article Material}

KD 3 Formula for article material in the 2013 curriculum revised edition for junior high school grade VIII: Understanding the content and configuration of social functions, the structure of articles and linguistic element. KD 4: Present and respond to article content by taking notice of social functions, as well as linguistic structure and elements. Whereas KD 3 formula for grade XII senior high school: Analyzing the content, structure and language aspects of Sundanese language articles. KD 4: Write a simple Sundanese article by noting to the structure and the use of language rules.

Noting KKO KD3 and KD4 of article material for Junior high school Class VIII are in the LOTs and HOTs categories i.e. understanding (C2) and presenting (C6). KKO for article material in Class XII senior High School both KD3 and KD4 also in the category of HOTs i.e. analyzing (C4), writing (C6). Based on the results of the analysis of KKO in KD 3 and 4 it is stated that the scope of the article material for junior high school is lower than for senior high school. It means that the article learning materials in senior high school is the continuation of the material taught in junior high school.

The material presented in RDBS for junior high school in the form facts includes the article text entitled "Kasenian Banda Urang" and "Hajat Babarit"; while for senior high school entitled "Seureuh" taken from CaharaBumiSiliwangi 
magazine and "Kina di Priangan" by Her Suganda taken from Cupumanik. The material in the form of concepts at junior high school includes: 1) the definition of article and 2) the concepts of article; while for senior high school it includes: 1) the definition of articles and 2) types of articles. The procedure for presenting material at junior high school consists of 1) reading the articles; 2) article content comprehension; 3 ) article structure; 4) composing the articles; 5) presenting the articles in various forms of media, 6) additional activities: various forms of rice, 7) vocabulary; high school level consists of: 1) reading articles; 2) article explanation; 3) analyzing article structure; 4) practicing drama; 5 ) rirect and indirect sentences ; 6) vocabulary.

\section{H. News Materials}

KD 3 formula for news material in the 2013 curriculum revised edition for junior high school class VIII: Identifying social functions, structures, and linguistic elements. KD 4: Expressions by paying attention to rhythm/tempo, articulation, and sentence tones. Whereas KD 3 formulation for grade XI senior high school: Analyzing the content, presentation patterns, and language aspects of news texts from printed or electronic mass media. KD 4: Composing news texts based on observations or interview results in accordance with the structure and language rules.

Noting KKO KD3 and KD4 news material in SMP Class VIII are in the category of LOTs and HOTs namely identifying (C1) and expressing (C6). KKO for news material in Class XII High School both KD3 and KD4 are also in the HOTs category, namely analyzing (C4), composing (C6). Based on the results of the analysis of KKO in KD 3 and 4 it is stated that the scope of the junior high school news material is lower than senior high school. It means that the learning material for news in senior high school is a continuation of learning for news from junior high school.

The material presented in the junior high school RDBS is in the form of facts i.e. the text entitled "RBS Miara Budaya Sunda"; while for the senior high school the text is entitled "Seni Unggulan Daerah Midang di Bandung". The material in the form of concepts at junior high school is about 1) news theme and 2) news formulation; for senior high school are: 1) the structure of the text includes the title, lead, body 2) the rules of the news text include the direct and the indirect sentence; 3) method of composing the news covers the $5 \mathrm{~W} 1 \mathrm{H}$. The procedure for presenting material at the junior high school is: 1) news analyzing; 2) explaining news; 3) news composing; 4) news reading; 5) additional activity: sentence of announcement; 6) vocabulary; while for senior high school it includes: 1) news text reading; 2) explaining news; 3) exploring the method of compiling news; 4) news composing; 5) additional activity: Sundanese musical instrument; 6) vocabulary.

\section{Speech Materials}

KD 3 Formulation for speech material in the 2013 Curriculum revised edition for junior high school Class IX: Understanding and identifying biantara speech texts by taking notice of social functions, text structures, and proper linguistic elements and contextual. KD 4: Presenting speech texts by giving the attention to social functions, structures, and proper linguistic elements and contextual. Whereas KD 3 formula for grade XI senior high school: Analyzing the content, structure, and linguistic aspects of speech. KD 4: Demonstrating speech by concerning to politeness and use of language rules.

Considering KKO KD3 and KD4 for speech material in junior high class IX is in category LOTs and HOTs namely understanding (C2) and Presenting (C6). KKO for speech material in class XI senior high School both KD3 and KD4 is also in the category of HOTs i.e. analyzing (C4), demonstrating (C6). Based on the results of the analysis of $\mathrm{KKO}$ on KD 3 and 4 It is stated that the scope of speech material in junior high school is lower than senior high school. It means speech learning material in Senior high school is the continuation of speech learning material in junior high school.

The material presented in junior high school RDBS is in the form of facts i.e the speech text entitled "Paturay Tineung" and head of student organization speech text entitled "Pekan Kreativitas Siswa"; and for senior high school is the speech text entitled "Paturay Tineung Class XII Students" and the speech text of teacher representative entitled "Pangjurung Laku". The material in the form of concepts at junior high school includes: 1) the definition of speech; 2) method of speech i.e. manuscript, memorized, extemporaneous, and impromptu; 3) method of speech abbreviated as TAGOG namely tatag (tough), alus (good), gerak (movement), omongan (speech), and gaya (style); 4) linguistic material of language style; 5) rarangkén tengah (infixes); while for senior high school it includes: 1) the definition of speech, 2) methods of speech, namely reasoning, manuscript, extemporaneous, and impromptu, 3) structure of speech i.e. bubuka (introduction), eusi (body), and panutup (conclusion) followed by examples. The procedure for presenting the material at junior high school starts from 1) reading the speech text, 2) mastering speech content, 3) method of speech, 4) speech decorative language 5) observing speech manuscripts, 6) additional activity: infixes, and 7) vocabulary; whereas at senior high school it started from 1) reading the speech textmaca téks, 2) explaining the speech, 3) comprehending the method of composing a speech 4) Delivering speeches, 5) additional activity: language manners, 6) vocabulary.

This section discusses the research findings of learning objectives as well as material types of facts and concepts, and their gradations. The objectives formulated in a textbook must be guided by the KIKD or Curriculum 2013. The learning objectives in the two books are written as learning signs for students who read them. With the formulation of these objectives, students are expected to be able to demonstrate the competence of their learning outcomes. Pophan and Baker (2005) stated that the learning objectives which initially focused more on mastering materials, then shifted to mastery of student abilities or commonly known as mastery of competencies or performance. Furthermore, Hamalik (2010, in Nulhakim, Wibawa, Erwin, Nuriah, \& Syahrial, 2018) states that in formulating learning objectives, one must pay attention to: components of terminal behavior, conditions and standards of measurement. 
In both books, not every learning objective is guided by the operational verbs in KIKD. There are still verbs that are difficult to measure, such as the verb maca (to read) and mahamkeun (to understand) allusion of poem is only repeating the operational verbs in KD. The two words in the formulation of the objectives are not quite correct, because "reading", like listening, is a process of understanding information from facts that leads students to have the expected competence. The correct operational verbs for reading allusion of poem are explaining, classifying, showing, and arranging. As stated by Dalman (2013) that the results of reading students are able to perfectly understand the reading content as well. This activity is a cognitive strategy, as stated by Brown (2007, in Eriyanti \& Wahyu, 2018), which is also called a communicative strategy as an activity in understanding reading, which is related to social mediation activities and interactions with others. Reading activities are the beginning of learning. Reading is also a survey to understand the material. Shoimin (2014) states that to arouse students' curiosity and motivation in learning begins with a survey of the reading at the beginning of learning. In line with Ngalimun's opinion (2014) that the survey at the beginning of learning can be started by reading the title and definition of each lesson. In addition, reading material can be absorbed through audio and visual media, as stated by Woolley (2010) that the provision of information by involving visual and auditory (verbal) processes can improve students' ability to understand reading. So, at the beginning of learning in the textbook, efforts are made to increase motivation to read, as stated by Patiung (2016) that the more we like the material we read, the easier it will be for us to remember its contents.

Another thing found from the results of the research was the facts types material in the textbook. Facts as learning material according to Arifin (2015) are all things that that manifest reality and truth, including the names of objects, historical events, symbols, names of places, names of people, names of parts or components of objects, and so on. Material types of facts presented include reading, listening, speaking, and writing texts. Dheini (2008) divided it into two groups i.e. the productive active language skills group and the receptive active language skills group (Harsch \& Hartig, 2016). Material types of facts are arranged in form of literary and non-literary texts $(\mathrm{Xu}, 2018)$. Each content of the text is deepened by students by reading it. As stated by Nunan (1989, in Dobao, 2012) that the material or content of the learning text must give attention to the gradation of text complexity, such as the presentation of simple sentences and complex sentences or single sentences and compound sentences.

In line with this opinion, Hamied (1987, in Tavakoli \& Foster, 2011) formulates several factors that need to be considered in selecting and grading language learning materials, including objectives, linguistic competence, time allocation, material selection. Regarding the process of understanding text, Nunan (1989, in Tavakoli \& Foster, 2011) states that text that is equipped with pictures, photos, tables, graphics will be easier to understand than text without pictures. The material presented in both prose and poetry in both books has been equipped with illustrations and pictures that are in accordance with the subject matter as well as its basic competencies. Therefore, through reading and listening, students have knowledge and abilities. As stated by Nana Sudjana (2013), teaching materials must be able to provide learning experiences for students. This is in line with what Sulistyowati and Sujadi (2015) states that success in teaching and learning activities is the goal of implementing education.

The type of concept material found in textbooks is generally related to literary material. However, the concept type material presented in both books is almost indistinguishable which material is for junior high school and which is for high school. In fact, the material for junior high school must be lower than high school. The concept discussed in a textbook must describe the background of the reader. Depdiknas (2003) formulates principles that must be considered in determining a learning approach i.e. learning is oriented to the principles of development and the of children's needs. Therefore, there is a need for material mapping for each level of education. This means that there must be differences in the scope of the conceptual material discussed at each level of education (Shaw, 2019; Li \& Xu, 2020). Hamied (1987, in Kholid, 2017) in his research results states that the gradation or improvement of language material is determined based on structural characteristics.

\section{CONCLUSIONS}

Based on the results of the analysis, there are 9 (nine) language learning materials and Sundanese literature written in RDBS book Junior high school (SMP/ MTs) and senior high school (SMA/MA/MAK) i.e. a) sisindiran, b) fairy tales, c) poetry, d) short story, e) novels, f) kawih, g) articles, h) news, and i) speech.

In general, the nine materials are in accordance with KIKD for Sundanese Language in the 2013 Revised curriculum. However, if we take a look to the level of material based on education levels, they failed to explain the gradation. This means that the material scope presented in junior high school does not have any difference, both in terms of the objectives, the material presented, and the evaluation. In futher details it can be described as follows: the formulation of learning objectives for junior and senior high schools is still dominant in the low category or Low Other Thinking Skills (LOTs), which are in the range of $\mathrm{C} 1, \mathrm{C} 2$, and $\mathrm{C} 3$; the learning material presented in the form of facts such as examples of discourse does not fully describe the gradations based on education level, i.e. the expected competencies for junior and senior high school students; the presentation of material in the form of concepts and principles does not yet describe the stages and scope of the material which is pursuant to the background of junior high and senior high school students; the evaluation instruments packaged through exercises and assignments have not been able to distinguish the abilities that junior high and senior high school students should possess; material in the form of facts, concepts, and principles have not taken any attention to the facts or text presented. The language elements expected in the KD formula are not clearly described; and the use of nonoperational verbs in constructing $\mathrm{KKO}$, 
such as the words maham, mahamkeun (comprehend), ngaragepkeun (listen), niténan (observe), maca (read).

\section{REFERENCES}

Arifin, M. S. (2015). Retrieved from http://muhsyamsularifin. blogs.uny.ac.id/wpcontent/uploads/sites/1979/2015/1 2/PENGEMBANGAN-MATERI-

PEMBELAJARAN.pdf.

Dalman. (2013). Keterampilan Membaca. Jakarta: Rajawali Pers.

Depdiknas. (2003). Kurikulum 2004 SMA: Pedoman Khusus Pengembangan Silabus dan Penilaian Mata Pelajaran Kimia. Jakarta: Ditjen Dikdasmen Direktorat Dikmenum, Depdiknas.

Dheini, N. (2008). Materi Pokok Metode Pengembangan Bahasa. Jakarta: Universitas Terbuka.

Dobao, A. F. (2012). Collaborative Writing Tasks in The L2 Classroom: Comparing Group, Pair, and Individual Work. Journal of Second Language Writing, 21(1), 40-58.

Eriyanti, \& Wahyu, R. (2018). Power Gap as One of the Trigger of Verbal Abuses Committed by Teachers in Schools. International Journal of Instruction, 11(1), 363-378.

Fauziah, U. (2015). Desain Penelitian Pengembangan Bahan Ajar IPA Terpadu Tema Cahaya dan Warna untuk Pembelajaran IPA SMP. Simposium Nasional Inovasi dan Pembelajaran Sains 2015, (pp. 573-576).

Haerudin, D. (2020). Gradasi Materi Buku Teks SMP dan SMA (Kajian Fakta, Konsep, Prinsip, dan Prosedur pada Bidang Studi Bahasa Sunda Kurikulum Mulok 2013 Revisi 2017). Seminar Internasional Riksa Bahasa, (pp. 1175-1184).

Harsch, C., \& Hartig, J. (2016). Comparing C-tests and Yes/No vocabulary size tests as predictors of receptive language skills. Language Testing, 33(4), 555-575. https://doi.org/10.1177/0265532215594642

Kholid, I. (2017). Motivasi Dalam Pembelajaran Bahasa Asing. English Education: Jurnal Tadris bahasa Inggris, 10(1), 61-71.

Li, Z., \& Xu, Y. (2020). Unpacking the Processes of Materials Use: An Interdisciplinary Perspective of Language Teachers' Use of Materials in China. SAGE Open. 113. https://doi.org/10.1177/2158244020977875

Mahmudah, R. (2016). Analisis kualitas buku teks pelajaran pendidikan agama Islam dan budi pekerti kelas VII Sekolah Menengah Pertama (SMP) Kurikulum 2013 di Kabupaten Malang. Undergraduate thesis, Universitas Islam Negeri Maulana Malik Ibrahim.

Ngalimun, S. P. (2014). Strategi dan Model Pembelajaran . Yogyakarta: Aswaja Pessindo.

Nulhakim, L., Wibawa, B., Erwin, T. N., Nuriah, T., \& Syahrial, Z. (2018). The Role of Teacher in Science Learning through Multiple Intelligences in Sekolah Peradaban Cilegon. 4(2), 148-157.

Nurdeani, R. (2014). Analisis Buku Teks Pelajaran Bahasa Inggris Berdasarkan Standar Penulisan Buku Teks Pelajaran (Penelitian Deskriptif Terhadap Buku Teks
Pelajaran Bahasa Inggris di Kelas III SD Negeri Layungsari Kecamatan Cihideung Kota Tasikmalaya). Jurnal Ilmiah Mahasiswa Pendidikan Guru Sekolah Dasar, 1(1), 1-9.

Patiung, D. (2016). Membaca Sebagai Sumber Pengembangan Intelektual. Al-Daulah Jurnal Hukum Pidana dan Ketatanegaraan, 5(2), 352-376.

Peraturan Menteri Pendidikan dan Kebudayaan Republik Indonesia No. 67 Tahun 2013 Kerangka Dasar dan Struktur Kurikulum Sekolah Dasar/Madrasah Ibtidaiyah.

Pophan, W. J., \& Baker, E. L. (2005). Tehnik Mengajar Secara Sistematis ( $4^{\text {th }}$ ed.). (A. Hadi, \& ddk., Trans.) Jakarta : PT. Rineka Cipta.

Shaw, R. S. (2019). The Learning Performance of Different Knowledge Map Construction Methods and Learning Styles Moderation for Programming Language Learning. Journal of Educational Computing Research, 56(8), 1-23. 14071429. https://doi.org/10.1177/0735633117744345

Shoimin, A. (2014). 68 Model Pembelajaran Inovatif dalam Kurikulum 2013. Yogyakarta: Ar-ruzz Media.

Sugiyono. (2008). Metode Penelitian Kuantitatif, Kualitatif dan $R \& D$. Bandung: Alfabeta.

Suistika, R. F., \& Ishartiwi. (2019). Development of Picture Book Media for Expressive Language Skills of Children with Autism. Indonesian Journal of EFL and Linguistics, 4(1), 27-39.

Sudjana, N. (2013). Penilaian Hasil Proses Belajar Mengajar. Bandung: PT Remaja Rosdakarya.

Sulistyowati, A., \& Sujadi, A. A. (2015). Analisis kesalahan dalam menyelesaikan soal sudut, luas, dan keliling segitiga siswa Kelas VII SMP Negeri 2 Mlati, Sleman. UNION: Jurnal Pendidikan Matematika, 3(3).

Suratni, \& Paat, J. (2014). Penelaahan Buku Teks Pelajaran Kurikulum 2013 Ditinjau dari Aspek Kelayakan Isi, Penyajian, Bahasa, dan Kegrafikaan. Jurnal Publipreneur, 2(3), 15-30.

Tavakoli, P., \& Foster, P. (2011). Task Design and Second Language Performance: The Effect of Narrative Type on Learner Output. Language Learning: A Journal of Research in Language Studies, 61(1), 37-72.

Woolley, G. (2010). Developing Reading Comprehension: Combining Visual and Verbal Cognitive Processes. Australian Journal of Language and Literacy, 33(2), 108-125.

$\mathrm{Xu}$, Z. (2018). Exploring English as an International Language - Curriculum, Materials and Pedagogical Strategies. RELC Journal, 49(1), 102-118. https://doi.org/10.1177/0033688217753848 